\title{
BIOLOGY OF ANTICARSIA GEMMATALIS ON SOYBEAN GENOTYPES WITH DIFFERENT DEGREES OF RESISTANCE TO INSECTS
}

\author{
Cristina Gomes Quevedo Fugi ${ }^{1}$; André Luiz Lourenção ${ }^{1 *}$; José Roberto Postali Parra ${ }^{2}$ \\ ${ }^{I} I A C$ - C.P. 28 - 13001-970 - Campinas, SP - Brazil. \\ ${ }^{2}$ USP/ESALQ - Depto. de Entomologia, Fitopatologia e Zoologia Agrícola, C.P. 09 - 13418-900 - Piracicaba, SP - \\ Brazil. \\ *Corresponding author <andre@iac.sp.gov.br>
}

\begin{abstract}
A knowledge of the mechanisms of resistance present in genetic materials should help breeding programs in developing cultivars resistant to insects. The biology of Anticarsia gemmatalis Hübner (Lepidoptera: Noctuidae) was studied on leaves of four soybean genotypes with different degrees of resistance to insects. The genotypes evaluated were cultivars IAC 17 and IAC 24, resistant to defoliators and stink bugs, line PI 229358, a source of multiple resistance to insects and used as parent in various lines selected for resistance to $A$. gemmatalis, and 'IAC PL-1', the susceptible control. The experiments were carried out in the laboratory, under controlled conditions of temperature $\left(25 \pm 2^{\circ} \mathrm{C}\right)$, relative humidity $(60 \pm 10 \%)$ and photoperiod (14h). First instar larvae were placed in Petri dishes and fed leaves of each genotype, detached from plants at the R1 and R2 stages (beginning and full bloom). Later on, insect couples were maintained in 25 PVC cages to evaluate parameters of the adult stage. 'IAC 17' and 'IAC 24' promoted low viability of the larval, pupal, and egg stages, causing adult deformation and a reduction of the number of eggs per female. PI 229358 prolonged the immature stage and reduced pupal weight, egg viability, and adult longevity. Considering all tests, 'IAC 17' and 'IAC 24' were characterized as having antibiosis-type resistance, and 'IAC PL-1' demonstrated to be a genotype suitable for insect development.
\end{abstract}

Key words: Glycine max, velvetbean caterpillar, host plant resistance

\section{BIOLOGIA DE ANTICARSIA GEMMATALIS EM GENÓTIPOS DE SOJA COM DIFERENTES GRAUS DE RESISTÊNCIA A INSETOS}

\begin{abstract}
RESUMO: O conhecimento do tipo de resistência presente em genótipos pode dinamizar programas de melhoramento que tenham essa finalidade. Assim, estudaram-se aspectos biológicos de Anticarsia gemmatalis Hübner (Lepidoptera: Noctuidae) em folhas de quatro genótipos de soja, sendo três com diferentes níveis de resistência e um suscetível a insetos. Avaliaram-se os cultivares IAC 17 e IAC 24, portadores de resistência a desfolhadores e sugadores, a linhagem PI 229358, progenitora de diversas linhagens resistentes a $A$. gemmatalis, e 'IAC PL-1' padrão de suscetibilidade. Os experimentos foram conduzidos em laboratório, sob condições controladas de temperatura $\left(25 \pm 2^{\circ} \mathrm{C}\right)$, umidade relativa $(60 \pm 10 \%)$, e fotofase $(14 \mathrm{~h})$. Larvas de primeiro ínstar foram acondicionadas em placas de Petri e alimentadas com folhas de cada um dos genótipos, retiradas de plantas nos estádios R1 e R2 (início e pleno florescimento). Posteriormente, casais foram mantidos em 25 gaiolas (tubo de PVC) para avaliar parâmetros da fase adulta. 'IAC 17' e 'IAC 24' proporcionaram baixa viabilidade das fases larval, pupal e de ovo, provocando deformação de adultos e diminuição do número de ovos por fêmea. PI 229358 alongou a fase imatura e reduziu o peso de pupas, viabilidade de ovos, e longevidade de adultos. Considerando-se todos os testes, os cultivares 'IAC 17' e 'IAC 24' ficam caracterizados como portadoras de resistência do tipo antibiose, e 'IAC PL-1' demonstra ser um genótipo adequado ao desenvolvimento do inseto.
\end{abstract}

Palavras-chave: Glycine max, lagarta-da-soja, resistência de plantas a insetos

\section{INTRODUCTION}

Among defoliating caterpillars, Anticarsia gemmatalis is the species that causes the greatest damages to soybean [Glycine max (L.)] in Brazil (HoffmannCampo et al., 2000). In order to complete their development, each caterpillar consumes about $90 \mathrm{~cm}^{2}$ of leaves (Leppla et al., 1977); thus, high infestations of this in- sect in soybean crops may compromise yield depending on the level of defoliation and phenological stage of the crop.

The use of plant resistance constitutes an excellent pest control method, harmonically integrating with other methods in pest management programs (IPM). Depending on the type involved, resistance may cause negative interferences on the biology and/or behavior of the 
insects, and also acts upon the plant's capability of withstanding high populations of the pest without significantly affecting yield (Painter, 1951). In the case of soybean, cultivars and lines with different levels of resistance have been obtained, especially by IAC (Miranda \& Lourenção, 2002). Thus, IAC line 78-2318, which has multiple resistance (Lourenção \& Miranda, 1987), and cultivars IAC 100 (Rosseto et al., 1987), IAC 17, and IAC 19 (Valle \& Lourenção, 2002), and IAC 23 and IAC 24 (Miranda et al., 2003a; 2003b) were obtained. The most important results that allowed the selection of this resistant material were obtained in the field. It is important to evaluate whether these cultivars/lines might adversely affect insect development, characterizing the occurrence of antibiosis and providing information that would allow the enhancement of breeding programs for this legume, targeted at incorporating resistance factors against insects.

Therefore, the objective of this research was to study biological aspects of $A$. gemmatalis maintained on leaves of four soybean genotypes, of which three presented different degrees of resistance to insects and one was susceptible, in order to determine the effect of the tested materials on the development of the insect.

\section{MATERIAL AND METHODS}

The studies were developed in Piracicaba, SP, Brazil, in a rearing room at a $25 \pm 2^{\circ} \mathrm{C}$ temperature, $60 \pm$ $10 \%$ relative humidity, and 14-hour photophase. The $A$. gemmatalis caterpillars were fed soybean leaves of genotypes 'IAC 17', 'IAC 24', 'IAC PL-1', and PI 229358.

Newly-hatched caterpillars were confined in acrylic dishes $(6.5 \mathrm{~cm} \emptyset \times 2 \mathrm{~cm} \mathrm{~h})$ and fed soybean leaves from the middle third of plants at the R1 and R2 stages (beginning and full bloom, respectively), according to Fehr \& Caviness' classification (1977). Each plot consisted of one dish containing one caterpillar, totaling 150 dishes for each genotype evaluated. The duration of the larval and pupal stages and their viabilities were evaluated, and the pupae had their sex determined and were weighed after 24 hours of age. Pupae that showed abdominal deformation were considered abnormal and were eliminated. The sex ratio was obtained by dividing the number of females by the sum of the number of females and males for each genotype. The presence of antibiosis in a genotype is characterized by a lack of adjustment in one or more developmental stages of the insect, caused by a reduction in viability, deformation, or even by an increase in the duration of the larval stage (Painter, 1951).

The head capsules of 25 caterpillars from each treatment were measured daily using a WILD MMS 235 ocular micrometer, attached to a stereoscopic microscope, to determine the number of instars. This procedure was repeated until the prepupal stage, when the caterpillars would change the distinctive color of their integument and would stop feeding. At this stage, each plot also consisted of one dish containing one caterpillar.

After emergence, the adults were classified into deformed and normal; deformed adults were eliminated, while normal individuals were maintained in collective cages for 48 hours to stimulate oviposition. Next, 25 couples from each treatment were paired up, and each couple was placed into a smaller cage (PVC tubes $12 \mathrm{~cm}$ in diameter by $20 \mathrm{~cm}$ height); a $10 \%$ honey solution was provided as food. The couples were used to evaluate adult longevity.

One sheet of sulfite paper lined the internal wall of the PVC tube to allow oviposition; the paper was replaced daily and the eggs from each couple were counted. Viability was evaluated based on a 30-egg sample from each of the first six egg layings of each couple. The number of hatched caterpillars was observed so a hatching percentage could be obtained.

A completely randomized design was used in these experiments. Data expressed as percentages were converted to arc sine $\sqrt{ } \mathrm{x} / 100$; other data were analyzed without transforms. The data were submitted to analysis of variance, and means were compared by Tukey test at $5 \%$, with the exception of the adult deformation and egg viability parameters, which were analyzed by the KruskalWallis non-parametric test. The Chi-square test $\left(\chi^{2}\right)$ was used for sex ratio.

\section{RESULTS AND DISCUSSION}

Effects of the genotypes on the development of the insect were detected, with the exception of the pupal period and sex ratio.

Larval stage - The values obtained for duration of the larval stage of caterpillars fed PI 229358, 'IAC 17', and 'IAC 24' leaves were longer than those obtained on 'IAC PL-1' (Table 1). In 'IAC 17', the data for the mean duration of this stage were similar to those verified by Gazzoni \& Tutida (1996), who obtained 13.7 days. 'IAC 24' and 'IAC 17 ' caused the mortality of more than $30 \%$ of the caterpillars that fed on their leaves, that is, only 68.6 and $66.2 \%$ reached the prepupal stage, respectively. This is due to the fact that, for these two genotypes, some caterpillars had their ecdysis blocked, and could not shed their skins or head capsules, while others showed a reduced body size in relation to their developmental time. In caterpillars fed PI 229358 these anomalies were not observed; however, the soybean line caused high mortality until the third instar of the insect.

Only PI 229358 affected the number of instars, increasing it to six (Figure 2B), while caterpillars that were fed the other three genotypes showed five instars (Figures 1A, 1B, and 2A). The presence of additional instars could be a reflex of nutritional inappropriateness 
Table 1 - Duration, viability, male (M) and female (F) pupal weight, and sex ratio corresponding to the larval, pre-pupal, and pupal stages of Anticarsia gemmatalis reared on leaves of four soybean genotypes with different degrees of resistance. Temperature: $25 \pm 2^{\circ} \mathrm{C}$; RH: $60 \pm 10 \%$, photophase: $14 \mathrm{~h}$.

\begin{tabular}{|c|c|c|c|c|c|c|c|c|}
\hline \multirow{3}{*}{ Genotype } & \multicolumn{2}{|c|}{ Larval stage* } & \multicolumn{2}{|c|}{ Prepupal stage* } & \multicolumn{3}{|c|}{ Pupal stage* } & \multirow{3}{*}{ Sex ratio** } \\
\hline & \multirow[t]{2}{*}{ Duration } & \multirow[t]{2}{*}{ Viability } & \multirow[t]{2}{*}{ Duration } & \multirow[t]{2}{*}{ Viability } & \multirow[t]{2}{*}{ Duration } & \multirow[t]{2}{*}{ Viability } & Weight & \\
\hline & & & & & & & M & \\
\hline & days & $\%$ & days & $\%$ & days & $\%$ & -.-- mg -..- & \\
\hline PI 229358 & $13.6 \mathrm{a}$ & $58.0 \mathrm{~b}$ & $1.4 \mathrm{a}$ & $95.0 \mathrm{ab}$ & $8.2 \mathrm{a}$ & $91.5 \mathrm{ab}$ & 231 a 189 a & $0.59^{\text {ns }}$ \\
\hline 'IAC 17' & $13.2 \mathrm{a}$ & $66.2 \mathrm{~b}$ & $1.1 \mathrm{~b}$ & $91.0 \mathrm{ab}$ & $8.2 \mathrm{a}$ & $81.4 \mathrm{~b}$ & $223 \mathrm{a}$ & $0.44^{\mathrm{ns}}$ \\
\hline 'IAC 24' & $13.0 \mathrm{a}$ & $68.6 \mathrm{~b}$ & $1.0 \mathrm{~b}$ & $86.0 \mathrm{~b}$ & $8.6 \mathrm{a}$ & $78.2 \mathrm{~b}$ & $178 \mathrm{a}$ & $0.52^{\mathrm{ns}}$ \\
\hline 'IAC PL-1' & $11.9 \mathrm{~b}$ & $95.1 \mathrm{a}$ & $1.0 \mathrm{~b}$ & $97.0 \mathrm{a}$ & $8.4 \mathrm{a}$ & 98.7 a & $206 a$ & $0.50^{\mathrm{ns}}$ \\
\hline Means & 12.9 & 72.0 & 1.1 & 92.2 & 8.3 & 87.4 & 229 A 193 B & \\
\hline C.V. $(\%)$ & 10.2 & 16.0 & 10.7 & 8.8 & 10.9 & 8.8 & & \\
\hline
\end{tabular}

*Means followed by different letters in the column are different by Tukey test at $5 \%$; $*$ Sex ratio $=$ females/females + males; ${ }^{\text {ns }}$ non significant by Chi-square test.

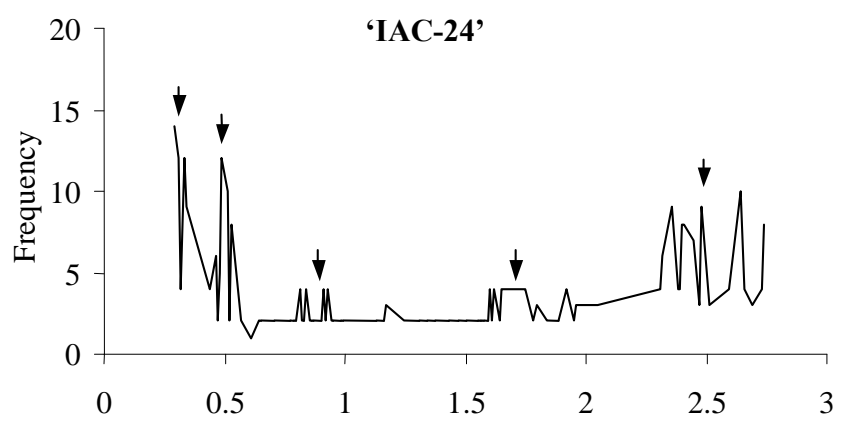

A)

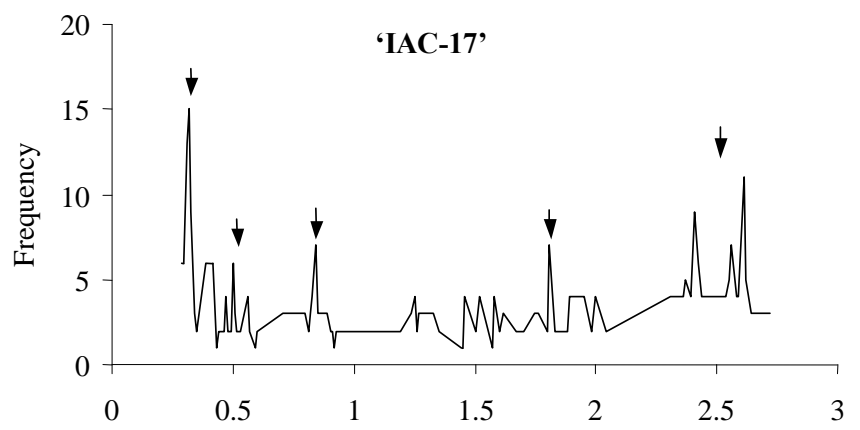

B)

Width of head capsules ( $\mathrm{mm})$

Figure 1 - Frequency and width of head capsules from Anticarsia gemmatalis caterpillars reared on 'IAC 24 ' and 'IAC 17 ' soybean leaves. Temperature: $25 \pm 2^{\circ} \mathrm{C}$; $\mathrm{RH}$ : $60 \pm$ $10 \%$, photophase: $14 \mathrm{~h}$.

(Slansky Jr. \& Rodriguez, 1987). When the hypothesis of occurrence of five instars is tested for treatments 'IAC 17', 'IAC 24', and 'IAC PL-1', and six instars for PI 229358, by the method developed by Parra \& Haddad (1989) based on Dyar's rule, coefficients of determination of $99 \%$ are obtained for all treatments, which reflects a good fitting of the data. Growth rate (K) ranged from 1.34 (PI 229358) to 1.71 ('IAC PL-1'); values of 1.61 for 'IAC 17' and 1.68 for 'IAC 24' were obtained.

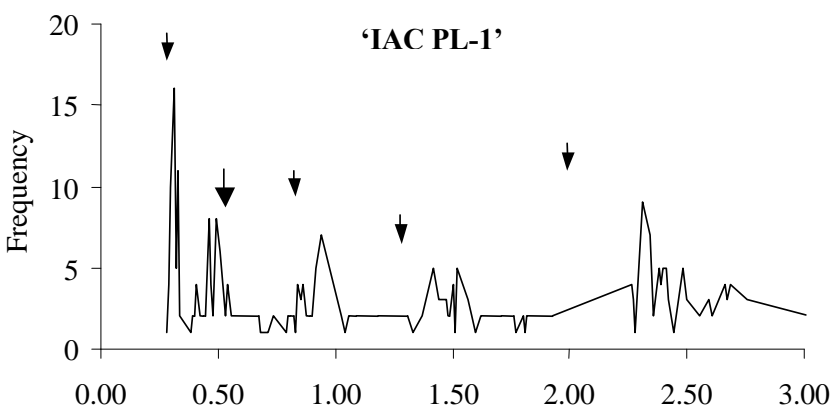

A)

Width of head capsules (mm)

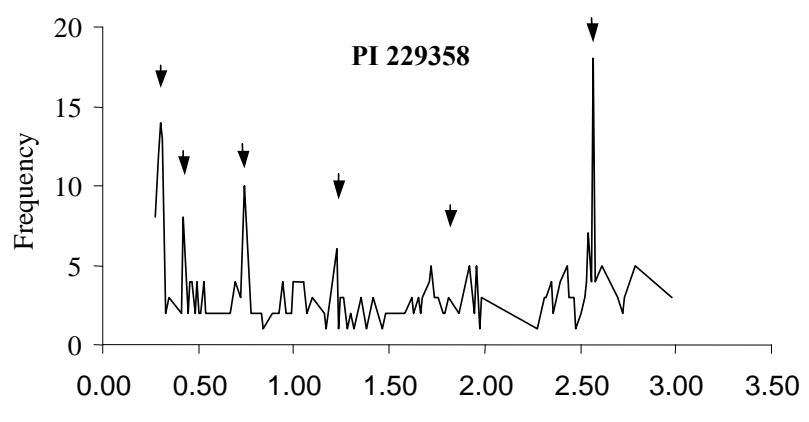

B)

Width of head capsules $(\mathrm{mm})$

Figure 2 - Frequency and width of head capsules from Anticarsia gemmatalis caterpillars reared on 'IAC PL-1' and PI 229358 soybean leaves. Temperature: $25 \pm 2{ }^{\circ} \mathrm{C}$; $\mathrm{RH}$ : $60 \pm 10 \%$, photophase: $14 \mathrm{~h}$.

Prepupal stage - The prepupal stage ranged from 1 to 1.4 day between genotypes (Table 1), and the mean duration was longer for caterpillars reared on PI 229358. These data are lower than those found by Gamundi (1988) (1.6 to 2 days) and Salvadori \& Corseuil (1982) (2.05 days) for this caterpillar species. Only in PI 229358 some caterpillars showed up to four days of duration for this stage, while in the other genotypes the variation was between one and two days. With regard to viability in this stage, 'IAC PL-1' obtained the highest value, with $97 \%$ 
of the prepupae reaching the pupal stage, thus demonstrating that it is a suitable material for this caterpillar, differing from 'IAC 24', which showed the smallest mean $(86.6 \%)$. The lower percentage provided by 'IAC 24 ' in relation to the other genotypes was due to a halt in the process of development into pupa, observed only in this genotype, a fact that was also observed in preliminary studies.

Pupal stage - Although the mean duration oscillated from 8.2 to 8.6 days (Table 1), the pupal stage ranged from 6 to 13 days, an interval similar to that obtained by Lourenção et al. (1996), who found 9 to 13 days working with this caterpillar on 'Santa Rosa' soybean. No differences were detected between genotypes for duration and weight. Genotype 'IAC PL-1' provided higher viability $(98.7 \%)$ when compared with 'IAC 17' (81.4\%) and 'IAC 24' (78.2\%). The values obtained for sex ratio were near 0.50 , which is a typical value for the species (Silva, 1981; Lourenção et al., 1996), and were not influenced by the genotypes, according to the Chi-square test.

Adult stage - Males lived longer than females (Table 2), a fact that had already been observed for this caterpillar species when reared on 'Santa Rosa' soybean (Lourenção et al., 1996). The mean number of eggs per egg-laying was higher for 'IAC PL-1' in relation to the other genotypes (Table 2). This cultivar provided a mean of 101.3 eggs, demonstrating a better suitability for the reproduction of A. gemmatalis. The mean for line PI $229358 \mathrm{did}$ not differ from the means for 'IAC 24' and 'IAC 17'. With regard to the total number of eggs, 'IAC PL-1' again provided the highest mean $(1,265.0$ eggs/female), a value about $73 \%$ higher than the other three genotypes, which were not different among themselves. In addition to a smaller total number of eggs, these three genotypes also induced a smaller number of eggs per egg-laying, indicating that these two cultivars and line PI 229358 condition the females to oviposit at smaller numbers when the caterpillars are reared on their leaves. Only adults resulting from feeding on 'IAC 17' and 'IAC 24' showed deformations characterized by wing anomalies, at percentages of $23.6 \%$ and $12.5 \%$, respectively (Table 2).

The incubation period was longer for eggs laid by adults whose caterpillars were reared on 'IAC 17', 'IAC 24', and PI 229358 (Table 2). Genotype 'IAC PL1 ' shortened the egg stage duration to 2.2 days. These results are inferior to those obtained by Magrini et al. (1996), who observed a mean incubation of 3.3 days at $27^{\circ} \mathrm{C}$, for eggs laid by adults whose caterpillars were reared on artificial diet.

Similarly as for the incubation period, differences were detected for the viability of eggs from females depending on plant genotype. Viability varied from $67.2 \%$ (PI 229358) to $95.2 \%$ ('IAC PL-1'). Again, this cultivar provided the best performance for this parameter, while 'IAC 24' and PI 229358 brought about the smallest viabilities.

It is concluded that cultivars IAC 17 and IAC 24 , in the same way as PI 229358, bear resistance of the antibiosis type, since feeding by $A$. gemmatalis caterpillars on their leaves led to negative effects in their development when compared with 'IAC PL-1'. The observation that 'IAC 17' and 'IAC 24' show antibiosis-type resistance, in addition to favorable agronomic characters, make these two cultivars greatly valuable for use in soybean breeding programs, as well as for planting in regions where the incidence of this pest is frequent.

Table 2 - Longevity of males (M) and females (F), number of eggs per egg-laying, number of eggs per female, deformation, duration, and viability corresponding to the adult and egg stages of Anticarsia gemmatalis reared on leaves of four soybean genotypes with different degrees of resistance to insects. Temperature: $25 \pm 2^{\circ} \mathrm{C}$; RH: $60 \pm 10 \%$, photophase: $14 \mathrm{~h}$.

\begin{tabular}{|c|c|c|c|c|c|c|c|}
\hline \multirow{3}{*}{ Genotype } & \multicolumn{5}{|c|}{ Adult stage } & \multicolumn{2}{|c|}{ Egg stage } \\
\hline & \multicolumn{2}{|c|}{ Longevity $*$} & \multirow[t]{2}{*}{ Eggs/egg-laying* } & \multirow[t]{2}{*}{ Eggs/female* } & \multirow[t]{2}{*}{ Deformation } & \multirow[t]{2}{*}{ Duration* } & \multirow[t]{2}{*}{ Viability** } \\
\hline & $\mathrm{M}$ & $\mathrm{F}$ & & & & & \\
\hline & \multicolumn{2}{|c|}{.......... days $-\ldots$} & & & $\%$ & days & $\%$ \\
\hline PI 229358 & $17.3 \mathrm{a}$ & $15.2 \mathrm{~b}$ & $72.4 \mathrm{~b}$ & $733.6 \mathrm{~b}$ & $0 \mathrm{~b}$ & $2.5 \mathrm{a}$ & $67.2 \mathrm{c}$ \\
\hline 'IAC 17' & $19.2 \mathrm{a}$ & $16.9 \mathrm{ab}$ & $65.3 \mathrm{~b}$ & $726.7 \mathrm{~b}$ & $12.5 \mathrm{ab}$ & $2.6 \mathrm{a}$ & $82.3 \mathrm{~b}$ \\
\hline 'IAC 24' & $18.4 \mathrm{a}$ & $16.2 \mathrm{ab}$ & $66.3 \mathrm{~b}$ & $730.3 \mathrm{~b}$ & $23.6 \mathrm{a}$ & $2.5 \mathrm{a}$ & $70.5 \mathrm{c}$ \\
\hline 'IAC PL-1' & $20.2 \mathrm{a}$ & $17.6 \mathrm{a}$ & $101.3 \mathrm{a}$ & $1265.0 \mathrm{a}$ & $0 \mathrm{~b}$ & $2.2 \mathrm{~b}$ & $95.5 \mathrm{a}$ \\
\hline Means & $18.8 \mathrm{~A}$ & $16.4 \mathrm{~B}$ & 76.3 & 863.9 & 9.0 & 2.4 & 78.9 \\
\hline C.V. $(\%)$ & 23.1 & 17.7 & 34.7 & 38.3 & 19.8 & & \\
\hline C.V. $(\%)$ sex $\times$ longevity & 21.4 & & & & & & \\
\hline
\end{tabular}

Sci. Agric. (Piracicaba, Braz.), v.62, n.1, p.31-35, Jan./Feb. 2005 


\section{ACKNOWLEDGEMENTS}

To FAPESP for support (Proceeding 01/12395-2), and to $\mathrm{CNPq}$, for scholarships granted to the second and third authors.

\section{REFERENCES}

FEHR, W.R.; CAVINESS, L.E. Stages of soybean development. Ames: Iowa State University Cooperative Extension Service, 1977. 12p. (Special Report, 80).

GAMUNDI, J.C. Biologia comparada e nutrição quantitativa de Anticarsia gemmatalis Hübner, 1818 (Lepidoptera: Noctuidae) em folhas e vagens de soja. Piracicaba:USP/ESALQ, 1988. 137p. (Dissertação - Mestrado).

GAZZONI, D.L.; TUTIDA, F. Efeito de genótipos resistentes e suscetíveis sobre a biologia da lagarta da soja (Anticarsia gemmatalis Hübner). Pesquisa Agropecuária Brasileira, v.31, p.709-714, 1996.

HOFFMANN-CAMPO, C.B.; MOSCARDI, F.; CORRÊA-FERREIRA, B.S.; OLIVEIRA, L.J.; SOSA-GOMEZ, D.R.; PANIZZI, A.R.; CORSO, I.C.; GAZZONI, D.L.; OLIVEIRA, E.B. Pragas da soja no Brasil e seu manejo integrado. Londrina: Embrapa Soja, 2000. 70p. (Circular Técnica, 30).

LEPPLA, N.C.; ASHLEY, T.R.; GUY, R.H.; BUTLER, G.D. Laboratory life history of the velvetbean caterpillar. Annals of the Entomological Society of America, v.70, p.217-220, 1977.

LOURENÇÃO, A.L.; MIRANDA, M.A.C. Resistência de soja a insetos: VIII. IAC 78-2318, linhagem com resistência múltipla. Bragantia, v.46, p.65-72, 1987

LOURENÇÃO, A.L.; COSTA, A.S.; PARRA, J.R.P.; AMBROSANO, G.M.B. Aspectos biológicos de Anticarsia gemmatalis Hübn. em soja sadia e infectada com o vírus do mosaico comum (SMV). Anais da Sociedade Entomológica do Brasil, v.25, p.47-57, 1996.

MAGRINI, E.A.; SILVEIRA NETO, S.; PARRA, J.R.P.; BOTELHO, P.S.M. Biologia e exigências térmicas de Anticarsia gemmatalis Hübner (Lepidoptera: Noctuidae) em laboratório. Anais da Sociedade Entomológica do Brasil, v.25, p.513-519, 1996.
MIRANDA, M.A.C.; LOURENÇÃO, A.L. Melhoramento genético da soja para resistência a insetos: uma realidade para aumentar a eficiência do controle integrado de pragas e viabilizar a soja orgânica. In: CONGRESSO BRASILEIRO DE SOJA E MERCOSOJA, 2., Foz do Iguaçu, 2002. Anais. Londrina: Embrapa Soja, 2002. p.52-60.

MIRANDA, M.A.C.; BRAGA, N.R.; LOURENÇÃO, A.L.; MIRANDA, F.T.S.; UNÊDA, S.H.; ITO, M.F. Descrição, produtividade e estabilidade da cultivar IAC-23, resistente a insetos. Bragantia, v.62, p.19-27, 2003a.

MIRANDA, M.A.C.; BRAGA, N.R.; LOURENÇÃO, A.L.; MIRANDA, F.T.S.; UNÊDA, S.H.; ITO, M.F. Descrição, produtividade e estabilidade da cultivar IAC-24, resistente a insetos. Bragantia, v. 62, p.29-37, 2003 b.

PAINTER, R.H. Insect resistance in crop plants. New York: MacMillan, 1951. p.23-83: The mechanisms of resistance.

PARRA, J.R.P.; HADDAD, M.L. Determinação do número de ínstares de insetos. Piracicaba: FEALQ, 1989. 49p

ROSSETTO, C.J.; TISSELI FILHO, O.; CIONE, J.; GALlO, P.B.; RAZERA, L.F.; TEIXEIRA, J.P.F. Cultivar de soja IAC 100. Campinas: IAC, 1987.

SALVADORI, J.R.; CORSEUIL, L. Consumo foliar e observações sobre o desenvolvimento de Anticarsia gemmatalis Hübner, 1818, em soja (Glycine $\max$ (L.) Merrill) (Lepidoptera, Noctuidae). Anais da Sociedade Entomológica do Brasil, v.11, p.93-100, 1982.

SILVA, R.F.P. Aspectos biológicos e nutrição de Anticarsia gemmatalis Hübner, 1818. (Lepidoptera - Noctuidae) em meios natural e artificial e influência da temperatura e fotoperíodo no seu desenvolvimento. Piracicaba:USP/ESALQ, 1981. 130p. (Tese - Doutorado).

SLANSKY Jr., F.; RODRIGUEZ, J.G. Nutricional ecology of insects, mites, spiders, and related invertebrates: an overview. In: SLANSKY Jr., F. RODRIGUEZ, J.G. (Ed.) Nutritional ecology of insects, mites, spiders, and related invertebrates. New York: J. Wiley \& Sons, 1987. p.1-69.

VALLE, G.E.; LOURENÇÃO, A.L. Resistência de genótipos de soja a Bemisia tabaci (Genn.) Biótipo B (Hemiptera: Aleyrodidae). Neotropical Entomology, v.31, p.285-295, 2002.

Received July 17, 2003

Accepted September 14, 2004 